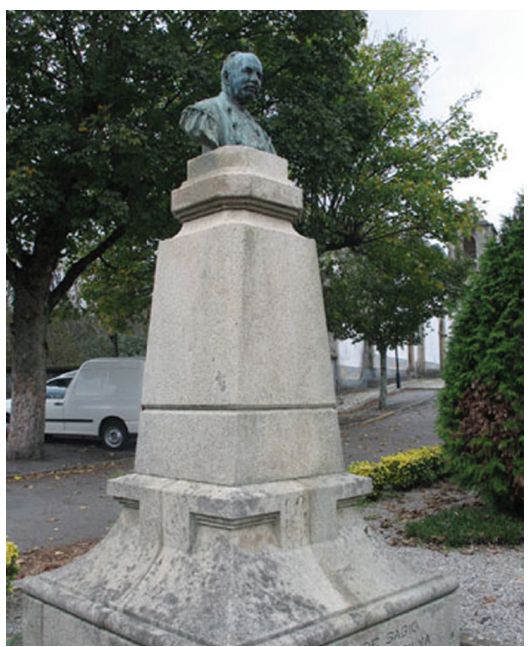

Busto de Ferreira da Silva, até há pouco tempo existente no largo da Igreja de Cucujães
Em Cucujães, Oliveira de Azeméis, existia há muitos anos, em frente à igreja local, um busto em bronze de um filho ilustre da terra, o químico Ferreira da Silva (1853-1923), fundador da Sociedade Portuguesa de Química.

Recentemente, e dada a vaga de roubos de estátuas de bronze no norte do país e na Galiza, a Junta de Freguesia mandou reforçar a base de sustentação do busto, para dificultar a sua retirada. Não foi contudo suficiente para evitar que este fosse furtado durante a noite. Dada a sua importância para a população local, a Junta de Freguesia irá tentar repor o busto, que era uma reprodução do existente na Faculdade de Ciências da Universidade do Porto, da autoria do escultor Teixeira Lopes.

Estima-se serem necessários $7.500 €$ a $10.000 €$ para a sua reposição. Segundo as palavras do Presidente da Junta de Freguesia de Cucujães, Sr. António Silva, "a freguesia ficou mais pobre com o furto deste seu património".

Joana Amaral (bquimica@ipb.pt) www.spq.pt

\title{
Notícias da Divisão de Química Analítica da IUPAC
}

A composição dos vários órgãos da IUPAC, representada em Portugal pela Sociedade Portuguesa de Química, é revista cada biénio. No biénio 2012-2013, a Divisão de Química Analítica (ACD-V) é presidida por Maria Filomena Camões (www.dqb.fc.ul. pt) que, nessa qualidade, integra também o Bureau.

Com o objetivo da promoção das várias áreas da Química Analítica, a Divisão apoia o desenvolvimento de projetos que poderão alargar-se a uma ou mais das 8 divisões existentes (www. iupac.org). O projeto prioritário da Divisão é, atualmente, a revisão do Orange Book, nome pelo qual é conhecido o livro de recomendações IUPAC relativo à Química Analítica, à semelhança dos nomes de diferentes cores atribuídas, respetivamente, a cada uma das outras divisões. A edição anterior, que pode ser acedida online, é a $3^{a}$ e data de 1998. Para a nova edição há uma estrutura de capítulos já definida que contempla os vários tipos de métodos de separação e de medição analítica, bem como uma seleção de áreas sectoriais de intervenção. Cada capítulo conta com um coordenador que, com as colaborações de que disponha, levará a tarefa a bom porto.

Um dos capítulos, da minha responsabilidade, é o de "Métodos de análise que assentam em medidas de massa e de volume", tema clássico, sempre renovado e promovido. Desejando-se fazer a mais ampla cobertura possível de termos e conceitos pertinentes, gostaria de abrir o repto aos colegas portugueses, aguardando manifestações de interesse em colaborar em propostas de entradas, que serão tomadas em devida consideração. Sugestões de outros projetos são igualmente bem vindas.

\section{Maria Filomena Camões}

(mfcamoes@fc.ul.pt)

Presidente da Divisão de Química Analítica da IUPAC

\section{Vá a www.spq.pt}

Torne-se Sócio da Sociedade Portuguesa de Química e beneficie de:

- Pertencer a uma comunidade científica dinâmica;

- Receber o boletim "QUÍMICA";

- Descontos nos Encontros promovidos pela SPQ;

- Descontos nas publicações da SPQ;

- Protocolos assinados entre a SPQ e outras entidades;

- Participar na promoção da Química;

- Apoiar uma Sociedade Científica.

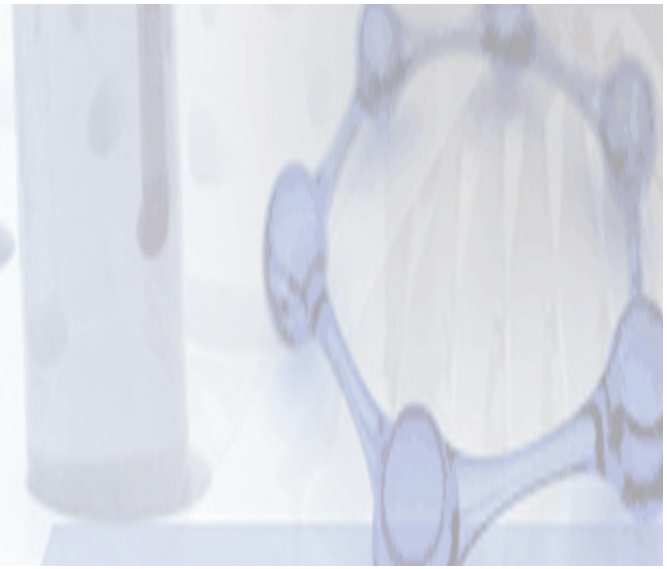

